\title{
28 Research Square \\ Hydrogen Peroxide Can Be a Plausible Biomarker in Cyanobacterial Bloom Treatment
}

Takashi Asaeda ( $\nabla$ asaeda@mail.saitama-u.ac.jp )

Saitama University

Mizanur Rahman

Saitama University

Helayaye Damitha Lakmali Abeynayaka

Saitama University

\section{Research Article}

Keywords: stresses, photoinhibition and nutrient depletion, growth of cyanobacteria

Posted Date: June 30th, 2021

DOl: https://doi.org/10.21203/rs.3.rs-650498/v1

License: (1) This work is licensed under a Creative Commons Attribution 4.0 International License.

Read Full License

Version of Record: A version of this preprint was published at Scientific Reports on January 7th, 2022.

See the published version at https://doi.org/10.1038/s41598-021-02978-6. 


\section{Abstract}

The effect of combined stresses, photoinhibition and nutrient depletion, on the oxidative stress of cyanobacteria was measured in laboratory experiments, to develop the biomass prediction model. Phormidium ambiguum was exposed to various photosynthetically active radiation (PAR) intensities and phosphorous concentrations with fixed nitrogen concentration. The samples were subjected to stress assays by detecting hydrogen peroxide $\left(\mathrm{H}_{2} \mathrm{O}_{2}\right)$ concentration and antioxidant activities of catalase (CAT) and superoxide dismutase (SOD). $\mathrm{H}_{2} \mathrm{O}_{2}$ concentration decreased to $30 \mu \mathrm{molm}^{-2} \mathrm{~s}^{-1}$ of PAR, then increased further with higher PAR intensity. Regarding phosphorus concentration, $\mathrm{H}_{2} \mathrm{O}_{2}$ concentration generally decreased with increasing phosphorus concentration. SOD and CAT activities were proportionate to the $\mathrm{H}_{2} \mathrm{O}_{2}$ protein ${ }^{-1}$. No $\mathrm{H}_{2} \mathrm{O}_{2}$ concentration detected outside of cells indicated the biological production of $\mathrm{H}_{2} \mathrm{O}_{2}$, and the accumulated $\mathrm{H}_{2} \mathrm{O}_{2}$ concentration inside cells was parameterized with $\mathrm{H}_{2} \mathrm{O}_{2}$ concentration protein ${ }^{-1}$. Over $30 \mu \mathrm{molm}^{-2} \mathrm{~s}^{-1}$ of PAR, $\mathrm{H}_{2} \mathrm{O}_{2}$ concentration protein ${ }^{-1}$ had a similar increasing trend with PAR intensity, independently of phosphorous concentration. Meanwhile, with increasing phosphorous concentration, $\mathrm{H}_{2} \mathrm{O}_{2}$ protein ${ }^{-1}$ decreased in a similar pattern regardless of PAR intensity. Protein content decreased with increasing $\mathrm{H}_{2} \mathrm{O}_{2}$ gradually up to $4 \mathrm{nmol} \mathrm{H}_{2} \mathrm{O}_{2} \mathrm{mg}^{-1}$ protein, which provides a threshold to restrict the growth of cyanobacteria. With these results. an empirical formula was developed to obtain the cyanobacteria biomass.

\section{Introduction}

Cyanobacteria blooms often produce toxic metabolites and are harmful for other organisms as well as humans. Hydrogen peroxide $\left(\mathrm{H}_{2} \mathrm{O}_{2}\right)$ is often endorsed to reduce the cyanobacterial abundance as it is more effective in application with cyanobacteria as compared to other phytoplankton ${ }^{1-2}$. However, $\mathrm{H}_{2} \mathrm{O}_{2}$ is also produced by other factors. First, hydrogen peroxide is generated photochemically from organic material exposed to $\mathrm{UV}$, and $\mathrm{H}_{2} \mathrm{O}_{2}$ distribution was observed in natural lakes ${ }^{3-5}$. At the same time, $\mathrm{H}_{2} \mathrm{O}_{2}$ is biologically produced in cells, exposed to environmental stresses, including metal ion toxicity, salinization, temperature, PAR conditions, eutrophication, allelopathy, and pathogens. though its contribution with respect to the total concentration is unknown ${ }^{5}$.

Under a stress environment, endogenous reactive oxygen species (ROS) production, including superoxide, hydroxyl radicals and $\mathrm{H}_{2} \mathrm{O}_{2}$ exceeds its scavenging capacity ${ }^{6-8}$. Reactive oxygen species are important for growth regulation and signaling mechanisms in photosynthetic organisms $s^{9-10}$ and those organisms in turn are capable of controlling excess ROS production with their inherent scavenging enzymes and nonenzymatic components ${ }^{9,11}$. Accumulation of an excessive amount of ROS inside cells causes harmful impacts on cyanobacteria such as disrupting the cellular homeostasis, causing membrane lipid peroxidation, protein oxidation, enzyme inhibition and DNA and RNA damages, etc., and affects the photosynthetic apparatus, finally leading to cell mortality as the concentration exceeds the threshold value $^{12}$. 
Cyanobacteria are sensitive to even a minor change in light intensity as they usually expose relatively weak light, and thus even a moderate solar radiation may cause stress ${ }^{13}$. Collecting solar energy at photosystem II (PSII) in the thylakoid membrane results in the oxidation of water molecules and the reduction of plastoquinone, a molecule involved in the electron transport chain. The produced electrons are transported to PSI, where they are consumed in the synthesis of carbohydrates. An overabundance of solar energy, however, results in the generation of ROS, including superoxide radicals, as the energy transfer rate is limited due to the underutilization of energy absorbed by the PSII antenna complex in the PSIl reaction center ${ }^{11,14-16}$. Superoxide dismutase (SOD) catalyzes superoxide radicals into hydrogen peroxide $\left(\mathrm{H}_{2} \mathrm{O}_{2}\right)$, before being detoxified into water by antioxidant activities ${ }^{17}$. However, the high oxidation potential of ROS can lead to the destruction of proteins, which otherwise recover the photosystem activities $^{18}$. Thus, excessive solar radiation inhibits the proliferation of cyanobacteria. The shortage of nutrient conditions is also identified as a dominant stressor that suppresses the growth of cyanobacteria ${ }^{19}$. The combined effect of various abiotic stresses on the production rate is often reported $^{20-21}$. Some combinations inhibit growth due to contradicting effects of stressors; however, significant reduction of biomass is also reported as caused by simultaneous exposure to multiple stressors as compared to a single source of stress $^{22}$.

The concentration of $\mathrm{H}_{2} \mathrm{O}_{2}$ and activity of antioxidant enzymes are some of the biomarkers employed in stress detections; and the role of $\mathrm{H}_{2} \mathrm{O}_{2}$, in plants and how they respond to environmental stress has been a focus throughout the literature ${ }^{23-25}$ suggesting a potential to develop ROS-based strategies for the prediction of cyanobacterial bloom formation and $\mathrm{H}_{2} \mathrm{O}_{2}$ concentration ${ }^{26}$. Thus, this research was designed to study (1) effects of the PAR regime and phosphorus concentration on the stress of cyanobacteria, particularly $\mathrm{H}_{2} \mathrm{O}_{2}$ concentration, (2) the combined effects of the PAR regime and phosphorous concentration on $\mathrm{H}_{2} \mathrm{O}_{2}$ concentration, and (3) the relationship between $\mathrm{H}_{2} \mathrm{O}_{2}$ concentration and antioxidant enzyme activities of cyanobacteria, aiming at the possibility of applying $\mathrm{H}_{2} \mathrm{O}_{2}$ concentration as a proxy to detect stress intensity in algal management and the contribution rate of biological $\mathrm{H}_{2} \mathrm{O}_{2}$ production rate in the treatment.

\section{Analyses}

\section{Total soluble protein content analysis}

Total soluble protein concentration was determined by using the same method that was mentioned in ${ }^{27}$ with minor modifications. Cyanobacterial cells were extracted from $1 \mathrm{~mL}$ of culture media by centrifugation at $4{ }^{\circ} \mathrm{C}$ for $10 \mathrm{~min}$ at $10,000 \mathrm{rpm}$, and the pellet was washed once with distilled water. Then, the cell pellet was subjected to a freeze-thaw cycle. Total soluble protein was extracted using $0.5 \mathrm{M}$ $\mathrm{NaOH}$ solution, and the extraction was centrifuged at $4{ }^{\circ} \mathrm{C}$ for $20 \mathrm{~min}$ at $10,000 \mathrm{rpm}$. The supernatant was used as crude protein extract, and the protein content was quantitatively analyzed with the aid of Coomassie Bradford protein assay kit. Crude protein extract was stained with Coomassie (G-250) dye and 
incubated for $10 \mathrm{~min}$ at room temperature, and then the absorbance was measured at $595 \mathrm{~nm}$ using a UV-Vis spectrometer (Shimazu, Japan). Protein content was determined using a known concentration series of Albumin.

\section{Stress assay}

\section{$\mathrm{H}_{2} \mathrm{O}_{2}$ Assay}

Cellular $\mathrm{H}_{2} \mathrm{O}_{2}$ contents were estimated according to the titanium chloride method ${ }^{28}$. A total of $750 \mu \mathrm{L}$ of $0.1 \%$ titanium chloride in $20 \% \mathrm{H}_{2} \mathrm{SO}_{4}(\mathrm{v} / \mathrm{v})$ was then added to initiate the reaction. The optical absorption after $1 \mathrm{~min}$ was measured at $410 \mathrm{~nm}$ using a spectrophotometer (UVmini-1240). However, the absorption at $410 \mathrm{~nm}$ includes the effect of other soluble compounds ${ }^{29-31}$. Thus, the $\mathrm{H}_{2} \mathrm{O}_{2}$ concentration was calculated from the slopes of the standard curve obtained from known $\mathrm{H}_{2} \mathrm{O}_{2}$ concentration, which was offset derived by the intercept absorption rate with zero $\mathrm{H}_{2} \mathrm{O}_{2}$ concentration samples ${ }^{30}$. The results were compared with those of the e-FOX method and the suitable agreement was obtained ${ }^{31}$.

\section{CAT assay}

The CAT activity was measured by reacting $15 \mu \mathrm{L}$ of $750 \mathrm{mM} \mathrm{H}_{2} \mathrm{O}_{2}, 920 \mu \mathrm{L}$ of potassium phosphate buffer, and $65 \mu \mathrm{L}$ of extract supernatant. Optical absorption was measured at $240 \mathrm{~nm}$ using UV mini1240. The measurements were recorded every $20 \mathrm{~s}$ for $3 \mathrm{~min}$, and CAT activity was calculated using an extinction coefficient of $39.4 \mathrm{mM}^{-1} \mathrm{~cm}^{32}$. Scavenging rate of $\mathrm{H}_{2} \mathrm{O}_{2}$ by enzyme extract per minute was defined as one unit of CAT per $1 \mu \mathrm{g}$ of protein.

\section{APX assay}

For APX assay, the reaction mixture contained $100 \mu \mathrm{L}$ of enzyme extract, $200 \mu \mathrm{L}$ of $0.5 \mathrm{mM}$ ascorbic acid in $50 \mathrm{mM}$ potassium phosphate buffer $(\mathrm{pH} \mathrm{7.0)}$ ), and $2 \mathrm{~mL}$ of $50 \mathrm{mM}$ potassium phosphate buffer $(\mathrm{pH}$ 7.0) was mixed with $60 \mu \mathrm{L}$ of $1 \mathrm{mM} \mathrm{H}_{2} \mathrm{O}_{2}$. The decrease in absorbance at $290 \mathrm{~nm}$ was recorded every 20 $\mathrm{s}$ for $3 \mathrm{~min}$. The APX activity was calculated using an extinction coefficient of $2.8 \mathrm{mM}^{-1} \mathrm{~cm}^{-1} 33$.

\section{SOD assay}

Total SOD activity was determined by using methods as described by ${ }^{34}$. The reaction mixture contained $50 \mathrm{mM}$ phosphate buffer ( $\mathrm{pH} 7.8$ ), $0.66 \mathrm{mM}$ EDTA, $10 \mathrm{mM}$ methionine, $33 \mu \mathrm{M} \mathrm{NBT}, 0.0033 \mathrm{mM}$ riboflavin and $50 \mu \mathrm{L}$ cyanobacterial enzyme extract. The reaction was allowed to proceed under a fluorescent illumination, after that the absorbance of the reaction mixture was read at $560 \mathrm{~nm}$. One unit of SOD activity was defined as the amount of enzymes required to cause $50 \%$ inhibition of the NBT photoreduction, and the results were expressed as unit per $\mu \mathrm{g}^{-1}$ of total soluble protein.

\section{Statistics}


Variance (ANOVA) and the bivariate analysis were used and Pearson's correlation method was followed to evaluate the relationship among parameters. Statistical analyses were performed with the help of IBM SPSS V25.

$\mathrm{H}_{2} \mathrm{O}_{2}$ concentration showed correlations with increasing PAR intensities and decreasing phosphorus concentrations, independently. The fitted curve patterns were different for each PAR intensity or each phosphorous concentration.

Therefore, the most fitted curves of $\mathrm{H}_{2} \mathrm{O}_{2}$ concentration with respect to phosphorus concentration, and with respect to PAR intensity, 30 to $200 \mu \mathrm{molm}^{-2} \mathrm{~s}^{-1}$, were obtained for each PAR intensity, and the phosphorus concentration, 0.1 to $1000 \mathrm{mgL}^{-1}$, respectively, then the effect of PAR intensity and phosphorus concentration in the $\mathrm{H}_{2} \mathrm{O}_{2}$ concentration was estimated.

The variance (ANOVA) and the bivariate analysis were used and Pearson's correlation method was followed to evaluate the relationship among parameters. Statistical analyses were performed with the help of IBM SPSS V25.

\section{Results}

\section{The effect of PAR intensity and phosphorous concentration on the $\mathrm{H}_{2} \mathrm{O}_{2}$ concentration}

Protein content and $\mathrm{H}_{2} \mathrm{O}_{2}$ concentration are shown in Fig1. Protein content for different PAR intensity levels and for each phosphorus concentration level $\left(\mathrm{mgL}^{-1}\right)$. Vertical bars indicate standard deviation and Fig2. H2O2 concentration for different PAR intensity levels and for each phosphorus concentration level $\left(\mathrm{mgL}^{-1}\right)$. Vertical bars indicate standard deviation. with respect to PAR intensity.

Protein content was higher in less than $50 \mu \mathrm{molm}^{-2} \mathrm{~s}^{-1}$ of PAR, and was observed to increase with increasing PAR intensity; $\mathrm{H}_{2} \mathrm{O}_{2}$ concentration per protein shows the similar variational trend with respect to the PAR intensity Fig. 3. H2O2 content per protein for different PAR intensity levels and for each phosphorus concentration level $\left(\mathrm{mgL}^{-1}\right)$. Vertical bars indicate standard deviation. Regardless of phosphorous concentration, it declined with low PAR intensities down to $30 \mu \mathrm{molm}^{-2} \mathrm{~s}^{-1}$ of PAR intensity and then increased gradually with decreasing enhancement rate. At values higher than $50 \mu \mathrm{molm}^{-2} \mathrm{~s}^{-}$ ${ }^{1}$ PAR, no significant difference with different phosphorus concentration levels was detected.

$\mathrm{H}_{2} \mathrm{O}_{2}$ per protein was generally lower with higher phosphorus concentration $(\mathrm{p}<0.03)$ Fig. 4. H2O2 content per protein for different phosphorus concentration level $\left(\mathrm{mgL}^{-1}\right)$ and for each PAR intensity level ( $\mu \mathrm{molm}^{-}$ $\left.{ }^{2} \mathrm{~s}^{-1}\right)$. Vertical bars indicate standard deviation. Dotted lines show the approximate relation for each light intensity.

$\mathrm{H}_{2} \mathrm{O}_{2}$ per protein, which was measured as high as 2.5 up to $10 \mu \mathrm{molm}^{-2} \mathrm{~s}^{-1}$, with 100 to $200 \mu \mathrm{molm}^{-2} \mathrm{~s}^{-1}$ of PAR intensities, declined with higher phosphorus concentration Fig. 4. H2O2 content per protein for 
different phosphorus concentration level $\left(\mathrm{mgL}^{-1}\right)$ and for each PAR intensity level $\left(\mu \mathrm{molm} \mathrm{m}^{-2} \mathrm{~s}^{-1}\right)$. Vertical bars indicate standard deviation. Dotted lines show the approximate relation for each light intensity.

Fig. 3. H2O2 content per protein for different PAR intensity levels and for each phosphorus concentration

level $\left(\mathrm{mgL}^{-1}\right)$. Vertical bars indicate standard deviation denotes the relationship between $\mathrm{H}_{2} \mathrm{O}_{2}$ per protein and PAR intensity for higher than $30 \mu \mathrm{molm}^{-2} \mathrm{~s}^{-1}$ of PAR intensity. For all phosphorus concentration levels, $\mathrm{H}_{2} \mathrm{O}_{2}$ per protein values had a similar pattern with respect to PAR intensity $(p<0.01)$.

\section{Antioxidant activities with respect to $\mathrm{H}_{2} \mathrm{O}_{2}$ concentration per protein}

SOD activity was uniquely proportionate to $\mathrm{H}_{2} \mathrm{O}_{2}$ per protein Fig. 5 . SOD activity per protein for different phosphorus concentration level $\left(\mathrm{mgL}^{-1}\right)$ and for each PAR intensity level $\left(\mu \mathrm{molm} \mathrm{m}^{-2} \mathrm{~s}^{-1}\right)$. The approximate relation is shown by the diagonal line, where $\mathrm{H}_{2} \mathrm{O}_{2} /$ protein $\left(\mathrm{nmolmg}^{-1}\right)=0.176(\mathrm{~min}) \star \mathrm{SOD}\left(\mathrm{nmolmg}^{-1} \mathrm{~min}^{-}\right.$ $\left.{ }^{1}\right),\left(R^{2}=-0.805, p<0.01\right)$.

CAT activity is shown as a function of $\mathrm{H}_{2} \mathrm{O}_{2}$ concentration per protein, separately shown by each phosphorous concentration Fig. 6. CAT activity per protein for different phosphorus concentration levels $\left(\mathrm{mgL}^{-1}\right)$. and for each PAR intensity level $\left(\mu \mathrm{molm}^{-2} \mathrm{~s}^{-1}\right)$. Dotted lines indicate the approximate lines for each phosphorus concentration. Overall CAT activity has a high correlation with $\mathrm{H}_{2} \mathrm{O}_{2}\left(n=90, \mathrm{R}^{2}=0.60\right.$, $p<0.01)$.

For each phosphorus concentration level, CAT activity per protein linearly increased with $\mathrm{H}_{2} \mathrm{O}_{2}$ /protein, and the increasing rate was higher based on PAR intensity $\left(18.73 \mathrm{CAT} / \mathrm{H}_{2} \mathrm{O}_{2}, \mathrm{R}^{2}=0.573\right.$ for $1000 \mathrm{mgPL}^{-1}$, 13.82CAT $/ \mathrm{H}_{2} \mathrm{O}_{2}, \mathrm{R}^{2}=0.977$ for $100 \mathrm{mgPL}^{-1} ; 12.89 \mathrm{CAT} / \mathrm{H}_{2} \mathrm{O}_{2}, \mathrm{R}^{2}=0.793$ for $10 \mathrm{mgPL} \mathrm{gL}^{-1} ; 14.53 \mathrm{CAT} / \mathrm{H}_{2} \mathrm{O}_{2}$, $\mathrm{R}^{2}=0.949$ for $1 \mathrm{mgPL}^{-1}$; and $9.22 \mathrm{CAT} / \mathrm{H}_{2} \mathrm{O}_{2}, \mathrm{R}^{2}=0.766$, for $0.1 \mathrm{mgPL}^{-1}$ ), and the proportional coefficient was found to have a significant positive correlation with the logarithmic scale of the phosphorus concentration $(p<0.01)$.

For each PAR intensity level, on the other hand, CAT activity did not have significant positive correlation with the phosphorous concentration level.

\section{Discussion}

\section{The effect of biologically produced $\mathrm{H}_{2} \mathrm{O}_{2}$ on the suppression of cyanobacterial blooms}

The artificial endorsement of $\mathrm{H}_{2} \mathrm{O}_{2}$ has a high potential to suppress cyanobacterial blooms with less effects on other organisms compared to other controlling methods ${ }^{35-39}$. Researchers obtained the lethal $\mathrm{H}_{2} \mathrm{O}_{2}$ concentration of cyanobacteria by laboratory incubations under different concentrations of $\mathrm{H}_{2} \mathrm{O}_{2}$; cyanobacterial chlorophyll declined to nearly half after $18 \mathrm{~h}$ with the dose of approximately $30 \mathrm{mmol}$ of $\mathrm{H}_{2} \mathrm{O}_{2} \mathrm{~L}^{-1} 1,40$ and in $4 \mathrm{~h}$ with $100 \mathrm{mmol}$ of $\mathrm{H}_{2} \mathrm{O}_{2} \mathrm{~L}^{-1} 2 . \mathrm{H}_{2} \mathrm{O}_{2}$ delayed fluorescence decay with $0.1 \mathrm{mmol}$ of 
$\mathrm{H}_{2} \mathrm{O}_{2} \mathrm{~L}^{-1} 37$, while the Fv/Fm value substantially declined with 100 mmol of $\mathrm{H}_{2} \mathrm{O}_{2} \mathrm{~L}^{-1}{ }^{41}$, dead cells increased with 275 mmol of $\mathrm{H}_{2} \mathrm{O}_{2} \mathrm{~L}^{-1} 39$. Cyanobacteria were in the lethal condition ${ }^{1-2}$ and sub-lethal at concentrations exceeding $50 \mathrm{mmol}$ of $\mathrm{H}_{2} \mathrm{O}_{2} \mathrm{~L}^{-1} 39$. All experimental results reveal that cyanobacterial biomass is degraded with higher $\mathrm{H}_{2} \mathrm{O}_{2}$ concentration; however, the threshold $\mathrm{H}_{2} \mathrm{O}_{2}$ concentration varies widely from 1 to $1000 \mathrm{mmol} \mathrm{L}^{-1}$.

Natural $\mathrm{H}_{2} \mathrm{O}_{2}$ formation has been identified in aquatic ecosystems as a photolysis of dissolved organic carbon (DOC) exposed to UV $3,42-44$ reported that the $\mathrm{H}_{2} \mathrm{O}_{2}$ production varies with the nutrient content of the water body. However, the $\mathrm{H}_{2} \mathrm{O}_{2}$ concentration of these waters was in the magnitude of $\mathrm{mmol}^{-1} 4,26,45$. The comparison of these results indicates that the photolysis of organic carbon in natural water only is not sufficient to control cyanobacterial biomass.

$\mathrm{H}_{2} \mathrm{O}_{2}$ is also produced biologically and is accumulated in cells, subject to high levels of environmental stress. In the present experiment, UV was limited. Accordingly, measured $\mathrm{H}_{2} \mathrm{O}_{2}$ was considered a biologically produced component in cells or cell surfaces, which was then released into the ambient water. In the present experiment, protein content was measured as a reference of biomass of cyanobacteria. Cell biomass is two to three times larger with the protein content ${ }^{46}$.

As the buoyancy of the cells is nearly neutral, the $\mathrm{H}_{2} \mathrm{O}_{2}$ content per protein, $\sim 1 \mathrm{mmol}$ of $\mathrm{H}_{2} \mathrm{O}_{2} \mathrm{~kg}^{-1}$ was generated and contained in the cell before release. This constitutes more or less the same level of the lethal $\mathrm{H}_{2} \mathrm{O}_{2}$ concentration in water.

The protein content in water declined with increasing $\mathrm{H}_{2} \mathrm{O}_{2}$ concentration per protein up to $2 \mathrm{nmol} \mathrm{mg}{ }^{-1}$ protein. A higher protein level was not observed with higher $\mathrm{H}_{2} \mathrm{O}_{2}$ concentration levels in the present study. The growth of cyanobacteria is suppressed by the generation of higher $\mathrm{H}_{2} \mathrm{O}_{2}$ levels.

The lethal $\mathrm{H}_{2} \mathrm{O}_{2}$ concentration obtained here corresponds well with about 5 mmol of $\mathrm{H}_{2} \mathrm{O}_{2} \mathrm{~g}^{-1} \mathrm{FW}$ of a threshold condition to grow Egeria densa in natural water ${ }^{25}$, considering the weakness of cyanobacteria to $\mathrm{H}_{2} \mathrm{O}_{2}$ rather than other plant species ${ }^{35}$.

\section{The possible indicator of environmental stress and the effect of combined stress factors}

The accumulation of ROS is reported to augment in parallel fashion to increased abiotic stress ${ }^{47-49}$. In the present experiment, two types of abiotic stresses, phosphorous deficiency and high or low PAR intensities were applied with different intensities of each.

Though $\mathrm{H}_{2} \mathrm{O}_{2}$ is produced under normal environmental conditions, their production is accelerated under high stress intensity. In natural water, cyanobacteria often suffer from a shortage of nitrogen and phosphorus. Stoichiometrically, the ratio of nitrogen and phosphorus of cyanobacterial cells is approximately $16: 1^{50}$. Waters with an $\mathrm{N}$ :P ratio of $<15$ are most susceptible to cyanobacterial 
dominance ${ }^{51-52}$. In the present experiment, the phosphorus concentration was changed with the fixed amount of nitrogen concentration of $3000 \mathrm{mg} \mathrm{L}^{-1}$. Thus, phosphorous concentration becomes restrictive, except for $1000 \mathrm{mg} \mathrm{P} \mathrm{L}^{-1}$ in the present study's conditions. A significant increasing trend was observed in $\mathrm{H}_{2} \mathrm{O}_{2}$ per protein with decreasing phosphorus concentration. The deficiency of restrictive nutrients may increase the oxidative stress and then deteriorate the growth rate.

Under all tested phosphorus concentrations, $\mathrm{H}_{2} \mathrm{O}_{2}$ per protein content decreased with increasing PAR intensity until $30 \mu \mathrm{molm}^{-2} \mathrm{~s}^{-1}$, taking the lowest value there, then increased at higher PAR intensities though increasing rate gradually decreased. The enhanced production of $\mathrm{H}_{2} \mathrm{O}_{2}$ under prolonged low PAR conditions has not been reported upon sufficiently, though the production of superoxide in dark conditions is reported ${ }^{26}$. With submerged macrophytes, Egeria densa, $\mathrm{H}_{2} \mathrm{O}_{2}$ concentration was empirically the lowest under the prolonged exposure of a PAR intensity level of approximately at $60 \mu \mathrm{molm}^{-2} \mathrm{~s}^{-1} 53$ and increased both with decreasing or increasing PAR intensities. However, the underlying mechanisms are unknown.

Increasing $\mathrm{H}_{2} \mathrm{O}_{2}$ concentration per protein over $30 \mu \mathrm{molm}^{-2} \mathrm{~s}^{-1}$ of PAR intensity is attributed to the excessive harvesting of PAR energy ${ }^{17-18}$. In the thylakoid membrane, electrons are produced by solar energy and transmitted to plastoquinone in PSII, which are partially accepted for the carbon dioxide fixation. More electrons are generated, when exposed to higher levels of solar radiation, and consequently, the photoinhibition of photosystem-II (PS-II) is induced, leading to oxidative damage because of the generated ROS, such as superoxide, hydroxyl radical, and $\mathrm{H}_{2} \mathrm{O}_{2}$. It damages cellular components, such as D1 protein, which otherwise mends the damaged photosynthesis apparatus ${ }^{18}$.

The process is composed of the direct reduction of $\mathrm{O}_{2}$ by PS-I resulting in the production of singlet oxygen, followed by superoxide, which is converted to $\mathrm{H}_{2} \mathrm{O}_{2}$ by the activities of the enzyme SOD.

In the present study, $\mathrm{H}_{2} \mathrm{O}_{2}$ per protein was proportionate with SOD activity, which generates $\mathrm{H}_{2} \mathrm{O}_{2}$ from superoxide. CAT activity was far higher than other major antioxidant activities to decompose $\mathrm{H}_{2} \mathrm{O}_{2}$, and linearly increased with $\mathrm{H}_{2} \mathrm{O}_{2}$ concentration.

Though SOD and CAT activities demonstrated different dependencies on PAR intensity levels and the phosphorus concentration, their activities were evaluated by the single function with $\mathrm{H}_{2} \mathrm{O}_{2}$ per protein. The steady $\mathrm{H}_{2} \mathrm{O}_{2}$ concentration is sustained by the balance of the generated $\mathrm{H}_{2} \mathrm{O}_{2}$ by different type of stresses and these antioxidant activities, as a single function of $\mathrm{H}_{2} \mathrm{O}_{2}$ content per protein.

In natural water, cyanobacteria are exposed to various types of abiotic stresses that enhance the oxidative stress, producing $\mathrm{H}_{2} \mathrm{O}_{2}$, and it may deteriorate cyanobacterial biomass. Significant negative correlation was recognized for protein content with respect to $\mathrm{H}_{2} \mathrm{O}_{2}$ concentration $\left(n=90, \mathrm{R}^{2}=-0.712\right.$, $p<0.01)$, irrespective of stress types. 
The production rate of $\mathrm{H}_{2} \mathrm{O}_{2}$ is not necessarily cumulative for different types of abiotic stresses ${ }^{22}$. However, $\mathrm{H}_{2} \mathrm{O}_{2}$ concentration was enhanced with increasing PAR intensity and decreasing phosphorus concentration, respectively, and the enhancement of $\mathrm{H}_{2} \mathrm{O}_{2}$ concentration was independent of each other $(p<0.01)$. The total $\mathrm{H}_{2} \mathrm{O}_{2}$ per protein is empirically given as the sum of the amount of $\mathrm{H}_{2} \mathrm{O}_{2}$ produced by the intensity of each stress component, at least as a practical use level. Thus, for the combined stresses, the total $\mathrm{H}_{2} \mathrm{O}_{2}$ concentration is approximately provided by the sum of the $\mathrm{H}_{2} \mathrm{O}_{2}$ concentration attributed to each stress. The same trend was obtained for submerged macrophytes ${ }^{25,53}$. Consequently, the potential to use the $\mathrm{H}_{2} \mathrm{O}_{2}$ concentration to estimate the cyanobacterial biomass exists.

\section{The estimation of $\mathrm{H}_{2} \mathrm{O}_{2}$ concentration produced by cyanobacteria under abiotic stresses}

For the application of the empirically obtained results to practical use in the prediction of algal blooms in the environment where PAR and phosphorous concentration, $\mathrm{P}$, are restricted factors for the growth, the trend of the $\mathrm{H}_{2} \mathrm{O}_{2}$ per protein ( $\mathrm{nmol} / \mathrm{mg}$ ) is obtained as a function of PAR $\left(\mu \mathrm{molm}^{-2} \mathrm{~s}^{-1}\right)$ and the phosphorous concentration, $\mathrm{P}\left(\mathrm{mgL}^{-1}\right)$, as formulated by

$\mathrm{H}_{2} \mathrm{O}_{2} /$ protein $=-312 * \mathrm{PAR}^{2} /\left(50^{2}+\mathrm{PAR}^{2}\right) *\left((25 / \mathrm{PAR})^{4}+1\right) \star \log (\mathrm{P} / 133100)$

Where $0.1 \mathrm{mg} \mathrm{P} \mathrm{L}^{-1}<\mathrm{P}<1000 \mathrm{mg} \mathrm{P} \mathrm{L}^{-1}$, and $30 \mu \mathrm{molm}^{-2} \mathrm{~s}^{-1}<\mathrm{PAR}$, and protein represents the amount of protein in $\mathrm{mgL}^{-1}$.

The relationship is shown in Fig. 8. The simulated results of $\mathrm{H}_{2} \mathrm{O}_{2}$ /protein by equation (1) compared with experimental results and a significant similarity was obtained $\left(R^{2}=0.953, p=0.012\right.$, for $1000 \mathrm{mg} \mathrm{PL}^{-1}$, $R^{2}=0.696, p=0.0065$ for $100 \mathrm{mg} \mathrm{P} \mathrm{L}^{-1} ; R^{2}=0.927, p=0.023$ for $20 \mathrm{mg} \mathrm{P} \mathrm{L}^{-1} ; \mathrm{R}^{2}=0.982, p=0.00289$ for $1 \mathrm{mg} P$ $L^{-1} ; R^{2}=0.024, p=0.024$ for $\left.0.1 \mathrm{mg} \mathrm{P} \mathrm{L}^{-1}\right)$.

The protein content $\left(\mathrm{mgL}^{-1}\right)$, as shown in Fig. 9. The simulated results of protein content by equation (2), as a function of $\mathrm{H}_{2} \mathrm{O}_{2}$ per protein was shown to possess significant negative correlation $\left(\mathrm{R}^{2}=-0.675\right.$, $p<0.01$ ), which is empirically formulated by

protein $=-192 * \log \left(\left(\mathrm{H}_{2} \mathrm{O}_{2} /\right.\right.$ protein $\left.) / 4.1\right)$

$\left(R^{2}=-0.71, p<0.01\right)$.

With equation (1) and (2), protein content is estimated as a function of PAR and the phosphorous concentration.

The estimated protein contents are denoted in Fig. 7. Protein content in water for different phosphorus concentration levels $(\mathrm{mg} / \mathrm{L})$ and for each PAR intensity level $\left(\mu \mathrm{molm} \mathrm{m}^{-2} \mathrm{~s}^{-1}\right)$. The concentration uniquely increased with increasing phosphorus concentration. 
The cellular growth rate gradually decreased with light intensity ${ }^{54}$, and the growth rate of cyanobacteria reached a maximum at 30 to $50 \mu \mathrm{molm}^{-2} \mathrm{~s}^{-1} 55$. P. ambiguum prefers relatively low light intensity, at $\sim 18$ $\mu \mathrm{molm} \mathrm{m}^{-2} \mathrm{~s}^{-1} \quad{ }^{56}$. The diagram seems to provide reasonable results.

\section{Conclusions}

Endogenous $\mathrm{H}_{2} \mathrm{O}_{2}$ concentration is an effective tool to detect the stress level of cyanobacteria.

Both PAR regimes and shortage of phosphorus concentration are shown to enhance $\mathrm{H}_{2} \mathrm{O}_{2}$ concentration in a cyanobacterial culture.

$\mathrm{H}_{2} \mathrm{O}_{2}$ per protein content declines in low PAR conditions, then increases when exposed to higher PAR intensity levels while generally increasing as phosphorus concentration decreases.

$\mathrm{H}_{2} \mathrm{O}_{2}$ per protein for combined stresses is given by the sum of the amount produced by each stress. Protein content decreases uniquely following the value of $\mathrm{H}_{2} \mathrm{O}_{2}$ per protein in a cyanobacterial culture. The prediction model was developed for the protein content, to design management criteria for excessive cyanobacterial blooms in freshwaters.

\section{Methodology}

\section{Culture and Incubation}

Phormidium ambiguum, which is an odor-forming benthic cyanobacterial species, was obtained from the National Institute of Studies (NIES), Japan. The strain was cultured and acclimatized for 30 days in an autoclaved BG 11 medium ${ }^{57}$, maintained at $20^{\circ} \mathrm{C}$ under controlled PAR conditions with white fluorescent light, having flux of $20 \mu \mathrm{molm}^{-2} \mathrm{~s}^{-1}$ in a light-and-dark cycle of $12 \mathrm{~h}: 12 \mathrm{~h}$. The cultures were manually shaken twice a day. Cells were subcultured by diluting with new BG 11 medium as needed ${ }^{27-28}$.

\section{Long-term exposure experiment}

After 30 days, well-grown cyanobacterial cells were collected by centrifugation, washed once with distilled water, and then re-suspended in modified BG 11 media. All experiments were conducted by using incubators (MIR-254, Sanyo, Tokyo, Japan) with a nutrient level of BG-11 medium, consisting of $\mathrm{NaNO}_{3}$ $17.6 \mathrm{mM}, \mathrm{K}_{2} \mathrm{HPO}_{4} 0.2296 \mathrm{mM}, \mathrm{MgSO}_{4} .7 \mathrm{H}_{2} \mathrm{O} 0.0146 \mathrm{mM}, \mathrm{Na} 2 \mathrm{CO} 30.0189 \mathrm{mM}$, Citric acid $0.0031 \mathrm{mM}$, Ferric ammonium citrate $0.0023 \mathrm{mM}$, EDTA ( $\mathrm{Na}_{2}$ salt) $0.0297 \mu \mathrm{M}, \mathrm{H}_{3} \mathrm{BO}_{3} 4.6253 \mu \mathrm{M}$, $\mathrm{MnCl}_{2} .4 \mathrm{H}_{2} \mathrm{O} 0.9145 \mu \mathrm{M}$, ZnSO4.7H2O $0.0765 \mu \mathrm{M}, \mathrm{Na}_{2} \mathrm{MoO}_{4} \cdot 2 \mathrm{H}_{2} \mathrm{O} 0.1611 \mu \mathrm{M}, \mathrm{CuSO}_{4} .5 \mathrm{H}_{2} \mathrm{O} 0.0316 \mu \mathrm{M}$, and $\mathrm{Co}\left(\mathrm{NO}_{3}\right)_{2} \cdot 6 \mathrm{H}_{2} \mathrm{O} 0.0023 \mu \mathrm{M}$ in $1 \mathrm{~L}$ of deionized water ${ }^{57}$, adjusted for nitrogen and phosphorus concentrations respectively at $3000 \mathrm{mgL}^{-1}$ of nitrogen and $0.1,1.0,10,100$, and $1000 \mathrm{mgL}^{-1}$ of phosphorus. Six different PAR intensities, namely - 10, 20, 30, 50, 100 and $200 \mu \mathrm{molm}^{-2} \mathrm{~s}^{-1}$ by white fluorescent light (Toshiba, Japan) and VBP-L24-C2 PAR source (Valore, Kyoto, Japan) were used with 
12h:12h PAR and dark cycle. The PAR intensities were measured using a quantum sensor (EKO Instruments Co., Ltd., Japan) and adjusted uniformly in the media. The temperature was kept constant $\left(20^{\circ} \mathrm{C}\right)$ throughout the experiment. At 12:00, after 7 days, samples were taken for the subsequent stress response analysis. Collected samples were subjected to bioassays that are described later.

\section{Short-term (one day) exposure experiment}

Another experimental setup was conducted to check the transition within a day of the culture. Above culture was exposed to $0,30,100$, and $300 \mu$ molm $^{-2} \mathrm{~s}^{-1}$ of PAR intensity with BG-11 medium, except for nitrogen and phosphorous concentrations, $250 \mathrm{mgL}^{-1}$ and $5.5 \mathrm{mgL}^{-1}$, respectively. A part of samples was taken at $6: 00$ (initial), 9:00, 12:00, 15:00, 18:00, 21:00, then was subjected to the analyses.

For both types, experimental units per each PAR and nutrient condition were triplicated in the same procedure, in order to confirm reproducibility.

\section{Declarations}

\section{Acknowledgement}

This work was financially supported by the Grant-in-Aid for Scientific Research (B) (19H02245) and the Fund for the Promotion of Joint International Research (18KK0116) of the Japan Society for the Promotion of Science (JSPS).

\section{Author contribution statement}

T.A. contributed to the design of the experiment, analyses, and writing the manuscript.

M.R. contributed to the revision of the manuscript.

H.D.L.A. carried out the experiment and writing the experiment part.

\section{References}

1. Barrington, D.J. \& Ghadouani, A. Application of hydrogen peroxide for the removal of toxic cyanobcteria and other phytoplankton from waste water. Environ. Sci. Technol. 42, 8916-8921 (2008)

2. Lurling, M., Meng, D. \& Fassen, E.L. Effects ot hydrogen peroxide and ultrasound on biomass reduction and toxin release in cyanobacterium, Microcytis aeruginosa. Toxins 6, 3260-3281 (2014)

3. Cooper, W.J., Zika, R., Petasne, R.G. \& Plane, J.M. Photochemical formation of hydrogen peroxide in natural waters exposed to sunPAR. Environ. Sci. Technol. 22, 1156-1160.

doi:10.1021/es00175a004 (1988) 
4. Cooper, W.J., Lean, D.R.S. \& Carey, J.H. Spatial and temporal patterns of hydrogen peroxide in lake waters. Can. J. Fish. Aquat. Sci. 46, 1227-1231. doi: 101139/f89-158 (1989)

5. Cory, R.M. et at. Seasonal dynamics in dissolved organic matter, hydrogen peroxide, and cyanobacterial blooms in Lake Erie. Frontiers in Marine Science, doi: 10.3389/fmars.2016.00054 (2016)

6. Caverzan, A., Passaia, G., Rosa, S.B., Ribeiro, C.W., Lazzarotto, F. \& Margis-Pinheiro, M Plant responses to stresses: role of ascorbate peroxidase in the antioxidant protection. Genet. Mol. Biol. 35, 1011-1019 (2012)

7. Sharma, P., Jha, A.B., Dubey, R.S. \& Pessarakli, M. Reactive oxygen species, oxidative damage, and antioxidative defense mechanism in plants under stressful conditions. J. Botany. (2012)

8. Ugya, A.Y., Imam, T.S., Li, A., Ma, J. \& Hua, X. Antioxidant response mechanism of freshwater microalgae species to reactive oxygen species production: a mini review. J. Chem. Ecol. 1-20 (2019)

9. Rastogi, R.P., Singh, S.P., Häder, D.-P. \& Sinha, R.P. Detection of reactive oxygen species (ROS) by the oxidant-sensing probe 2',7'-dichlorodihydrofluorescein diacetate in the cyanobacterium Anabaena variabilis PCC 7937. Biochem. Biophys. Res. Commun. 397, 603-607 (2010)

10. Foyer, C.H. Reactive oxygen species, oxidative signaling and the regulation of photosynthesis. Environ. Exp. Bot. 154, 134-142 (2018)

11. Gill, S.S. \& Tuteja, N. Reactive oxygen species and antioxidant machinery in abiotic stress tolerance in crop plants. Plant Physiol. Biochem. 48, 909-930 (2010)

12. Ma, Z. \& Gao, K. Spiral breakage and photoinhibition of Arthrospira platensis (Cyanophyta) caused by accumulation of reactive oxygen species under solar radiation. Environ. Exp. Bot. 68, 208-213 (2010)

13. Welkie, D.G. et al. A hard day's night: Cyanobacteria in Diel cycles. Trends Microbiol. 27, 231$242(2019)$

14. Latifi, A., Ruiz, M. \& Zhang, C.C. Oxidative stress in cyanobacteria. FEMS Microbiol. Rev. 33, 258-278 (2009)

15. Lea-Smith, D.J., Bombelli, P., Vasudevan, R. \& Howe, C.J. Photosynthetic, respiratory and extracellular electron transport pathways in cyanobacteria. Biochimica et Biophysica Acta (BBA)Bioenergetics 1857, 247-255 (2016)

16. Raja, V., Majeed, U., Kang, H., Andrabi, K.I. \& John, R. Abiotic stress: Interplay between ROS, hormones and MAPKs. Environ. Exp. Bot. 137, 142-157 (2017) 
17. Asada, S., Fukuda, K., Oh, M., Hamanishi, C. \& Tanaka, S. Effect of hydrogen peroxide on the metabolism of articular chondrocytes. Inflamm. Res. 48, 399-403 (1999)

18. Nishiyama, Y. \& Murata, N. Revised scheme for the mechanisms of photoinhibition and its application to enhance the abiotic stress tolerance of the photosynthetic machinery. Appl. Microbiol. Biotechnol. 98, 8777-8796 (2014)

19. Mikula, P., Zezulka, S., Jancula, D. \& Marsalek, B. Metabolic activity and membrane integrity changes in Microcystis aeruginosa - new findings on hydrogen peroxide toxicity in cyanobacteria. Eur. J. Phycol. 47, 195-206 (2012)

20. Mittler, R. Abiotic stress, the field environment and stress combination. Trends in plant science, 11, 15-19. doi:10.1016/j.tplants.2005.11.002 (2006)

21. Saints, M., Diaz, P., Monza, J. \& Borsani, O. Heat stress results in loss of chloroplast Cu/Zn superoxide dismutase and increased damage to Photosystem II in combined drought-heat stressed Lotus japonicus. Physiological Plantarum 140, 46-56. doi:10.111/j.1399-3054.2010.01383.x (2010)

22. Suzuki, N., Rivero, R.M., Shulaev, V., Blumwald, E. \& Mittler, R. Abiotic and biotic stress combinations. New Phytologist 203, 3-43. doi:10.1111/nph.12797 (2014)

23. Asaeda, T. \& Barnuevo, A. Oxidative stress as an indicator of niche-width preference of mangrove Rhizophora stylosa. Forest Ecology and Management 432, 73-82 (2019)

24. Asaeda, T., Senavirathna, M.D.H.J., Vamsi Krishna, L. \& Yoshida, N. Impact of regulated water levels on willows (Salix subfragilis) at a flood-control dam, and the use of hydrogen peroxide as an indicator of environmenal stress. Ecological Engineering, 127, 96-102 (2019)

25. Asaeda, T., Senavirathna, M.D,H.J. \& Vamsi Krishna, L. Evaluation of habitat preferance of invasive macrophyte Egeria densa in different channel slopes using hydrogen peroxide as an indicator. Froniters in Plant Science 11.422, doi:10.3389/fpls.2020.00422 (2020)

26. Diaz, J. \& Plummer, S. Production of extracellular reactive oxygen species by phytoplankton: past and future directions. J. Plankton Res. 40, 655-666 (2018)

27. Abeynayaka, H.D.L., Asaeda, T. \& Kaneko, Y. Buoyancy limitation of filamentous cyanobacteria under prolonged pressure due to the gas vesicle collapse. Env. Man. 60, 293-303 (2017)

28. Jana, S. \& Choudhuri, M.A. Glycolate metabolism of three submersed aquatic angiosperms during ageing. Aquatic Botany 12, 345-354 (1982)

29. Veljovic-Jovanovic S., Noctor G. \& Foer C.H. Are leaf hydrogen peroxide concentrations commonly overestimated? The potential influence of artefactual interference by tissue phenolics and ascorbate. Plant Physiology and Biochemistry 28, 318-327 (2002) 
30. Cheeseman, J.M. Hydrogen peroxide concentrations in leaves under natular conditions. J. Exp. Bot. 57, 2435-2444 (2006)

31. Queval, G., Hager J., Gakiere, B. \& Noctor, G. Why are literature data for $\mathrm{H}_{2} \mathrm{O}_{2}$ contents so variable? A discussion of potential difficulties in the quantitative assay of leaf extracts. J.Exp. Bot. 59, 135-146. doi:10.1093/jxb/em193 (2008)

32. Aebi, H. Catalase in vitro. Methods in Enzymology 105, 121-126 (1984)

33. Nakano, Y. \& Asada, K. Hydrogen peroxide is scavenged by ascorbate-specific peroxidase in spinach chloroplasts. Plant Cell Physiol. 22, 867-880 (1981)

34. Ahmad, P., Jaleel, C.A., Salem, M.A., Nabi, G. \& Sharma, S. Roles of enzymatic and non enzymatic antioxidants in plants during abiotic stress. Cri. Rev. in Biotech. 30, 161-175 (2010)

35. Drábková, M., Admiraal, W. \& Maršálek, B. Combined exposure to hydrogen peroxide and PAR -selective effects on cyanobacteria, green algae, and diatoms. Environ. Sci. Technol. 41, 309-314 (2007a)

36. Bouchard, J.N. \& Purdie, D.A. Effect of elevated temperature, darkness and hydrogen peroxide treatment on oxidative stress and cell death in the bloom-forming toxic cyanobacterium Microcystis aeruginosa. J. Phycol. 47, 1316-1325 (2011)

37. Leunert, F., Eckert, W., Paul, A., Gerhardt, V. \& Grossart, H.P. Phytoplanktonic response to UVgenerated hydrogen peroxide from natural organic matter. J. Plankton Res. 36, 185-197. doi:10.1093/plankt/fbt096 (2014)

38. Wang, B., Song, Q., Long, J., Song, G., Mi, W. \& Bi, Y. Optimization method for Microcystis bloom mitigation by hydrogen peroxide and its stimulative effects on growth of chlorophytes. Chemosphere 228, 503-512 (2019)

39. Foo, S.C., Chapman, I.J., Hartnell, D.M., Turner, A.D. \& Franklin D.J. Effects of $\mathrm{H}_{2} \mathrm{O}_{2}$ on growth, metabolic activity and membrane integrity in three strains of Microcystis aeruginosa. Env. Sci. Poll. Res. 27, 38916-38927 (2020)

40. Barrington, D.J., Reichwaldt, E.S. \& Ghadouani, A. The use of hydrogen peroxide to remove cyanobacteria and microcystins from waste stabilization ponds and hypereutrophic systems. Ecol. Engin. 50, 86-94 (2013)

41. Drábková, M., Matthijs, $\mathrm{H}$., Admiraal, W. \& Maršálek, B. Selective effects of $\mathrm{H}_{2} \mathrm{O}_{2}$ on cyanobacterial photosynthesis. Photosynthetica. 45, 363-369 (2007b) 
42. Cooper, W.J., Zika, R., Petasne, R.G. \& Plane, J.M. Photochemical formation of hydrogen peroxide in natural waters exposed to sunPAR. Environ. Sci. Technol. 22, 1156-1160. doi:10.1021/es00175a004 (1988)

43. Garcia, P.E., Queimalinos, C. \& Dieguez, M.C. Natural levels and photo-production rates of hydrogen peroxide $\left(\mathrm{H}_{2} \mathrm{O}_{2}\right)$ in Andean Patagonian aquatic sysyems: Influence of the dissolved organic matter pool. Chemosphere. 217, 550-557 (2019)

44. Herrmann, R., 1996. The daily changing pattern of hydrogen peroxide in New Zealand surface waters. Environm. Toxicol. \& Chem. 15, 652-662.

45. Spoof, L. et al. Elimination of cyanobacteria and microcystins in irrigation water - Effects of hydrogen peroxide treatment. Env. Sci. Poll. Res. 27, 8638-8652. doi.org/10.1007/s1 1356-019-07476-x (2020)

46. Lopez, C.V.G. et al. Protein measuremements of microalgae and cyanobacterial biomass. Bioresource Technol. 101, 7587-7591 (2010)

47. Vesterkvist, P.S.M., Misiorek, J.O., Spoof, L.E.M., Toivola, D.M. \& Meriluoto, J.A.O. Comparative cellular toxicity of hydrophilic and hydrophobic Microcystins on Caco-2 Cells. Toxins 4, 1008 (2012)

48. Preece, E.P., Hardy, F.J., Moore, B.C. \& Bryan, M. A review of microcystin detections in estuarine and marine waters: Environmental implications and human health risk. Harmful Algae 61, 31-45 (2017)

49. Pham, T.-L. \& Utsumi, M. An overview of the accumulation of microcystins in aquatic ecosystems. J. Environ. Manag. 213, 520-529 (2018)

50. Goldman, J.C., McCarthy, J.J., D.G. \& Peavey, D.G. Growth rate influence on the chemical composition of phytoplankton in oceanic waters. Nature 279, 210215 (1979)

51. Paerl, H.W., Fulton, R.S. 3rd, Moisander, P.H. \& Dyble, J. Harmful freshwater algal blooms, with an emphasis on cyanobacteria. Scient. World J. 12805693, PMC6083932 (2001)

52. Xie, L., Xie, P., Li, Sixin, Tang, H. \& Liu, H. The low TN:TP ratio, a case or result of Microcystis blooms? Water Res. 37, 2070-2080 (2003)

53. Asaeda, T., Rashid, Md.H., \& Schoelynck, J. Tissue Hydrogen Peroxide Concentration Can Explain 58. the Invasiveness of Aquatic Macrophytes: A Modeling Perspective. Front. Environ. Sci. 8, (2021)

54. Hesse, K., Dittman, E., Borner, T., 2001. FEMS microbiology ecology 37, 39-43.

55. Tilzer, M.M. Light dependence of photosynthesis and growth in cyanobacteria: Implications for their dominance in eutrophic lakes. N. Z. J. Mar. Freshw. Res. 21, 401-412 (1987) 
56. Iwase, S. \& Abe,Y.. Identification and change in concentration of musty-odor compounds during growth in blue-green algae. J. Scool Mar. Sci. Tech. 8, 27-33 (2010)

57. Rippka, R., Deruelles, J., Waterbury, J.B., Herdman, M. \& Stanier, R.Y. Generic assignments, strain histories and properties of pure cultures of cyanobacteria. Microbiology 111, 1-61 (1979)

\section{Figures}

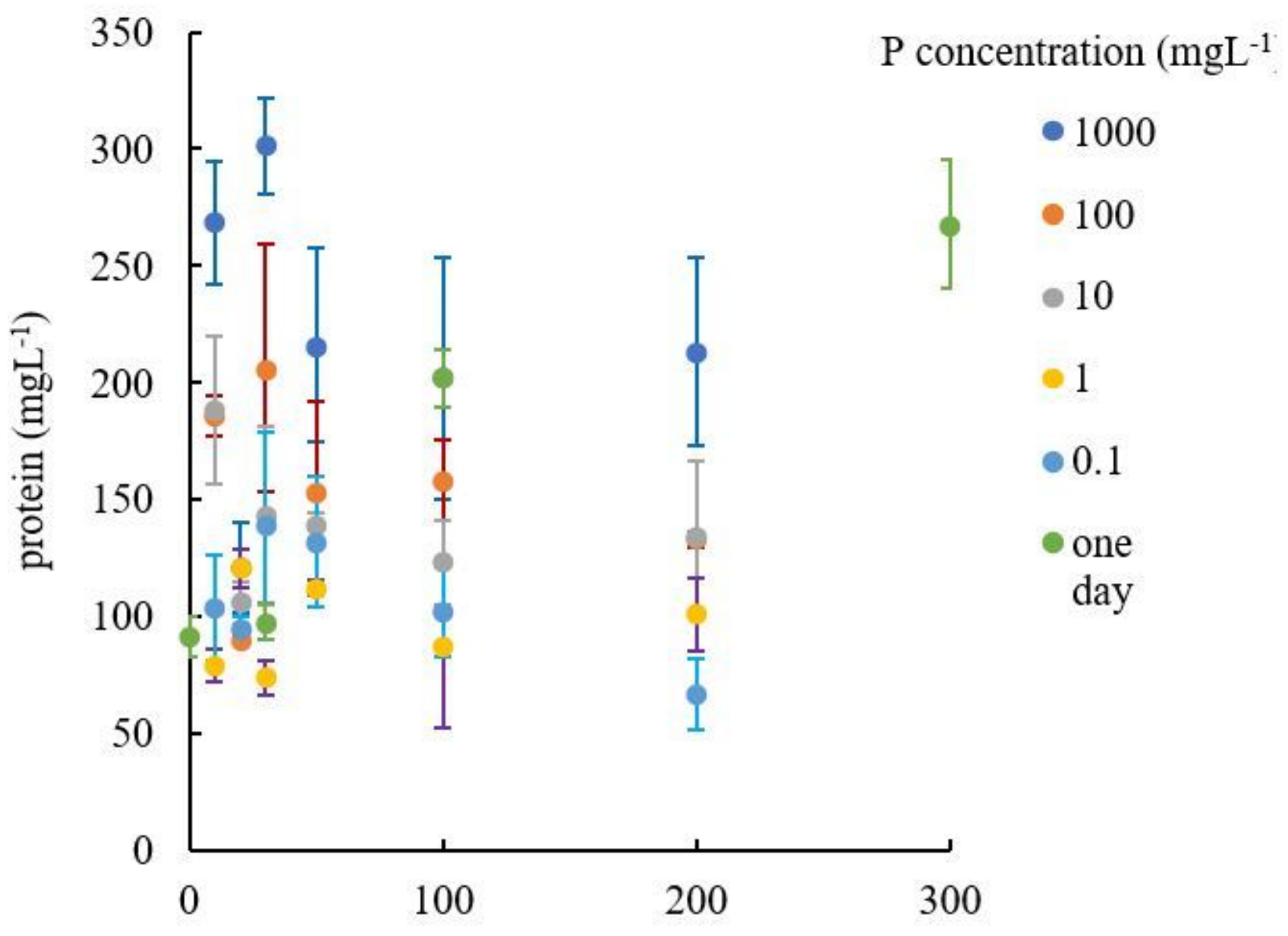

$\operatorname{PAR}\left(\mu \mathrm{molm}^{-2} \mathrm{~s}^{-1}\right)$

\section{Figure 1}

Protein content for different PAR intensity levels and for each phosphorus concentration level (mgL-1). Vertical bars indicate standard deviation. 


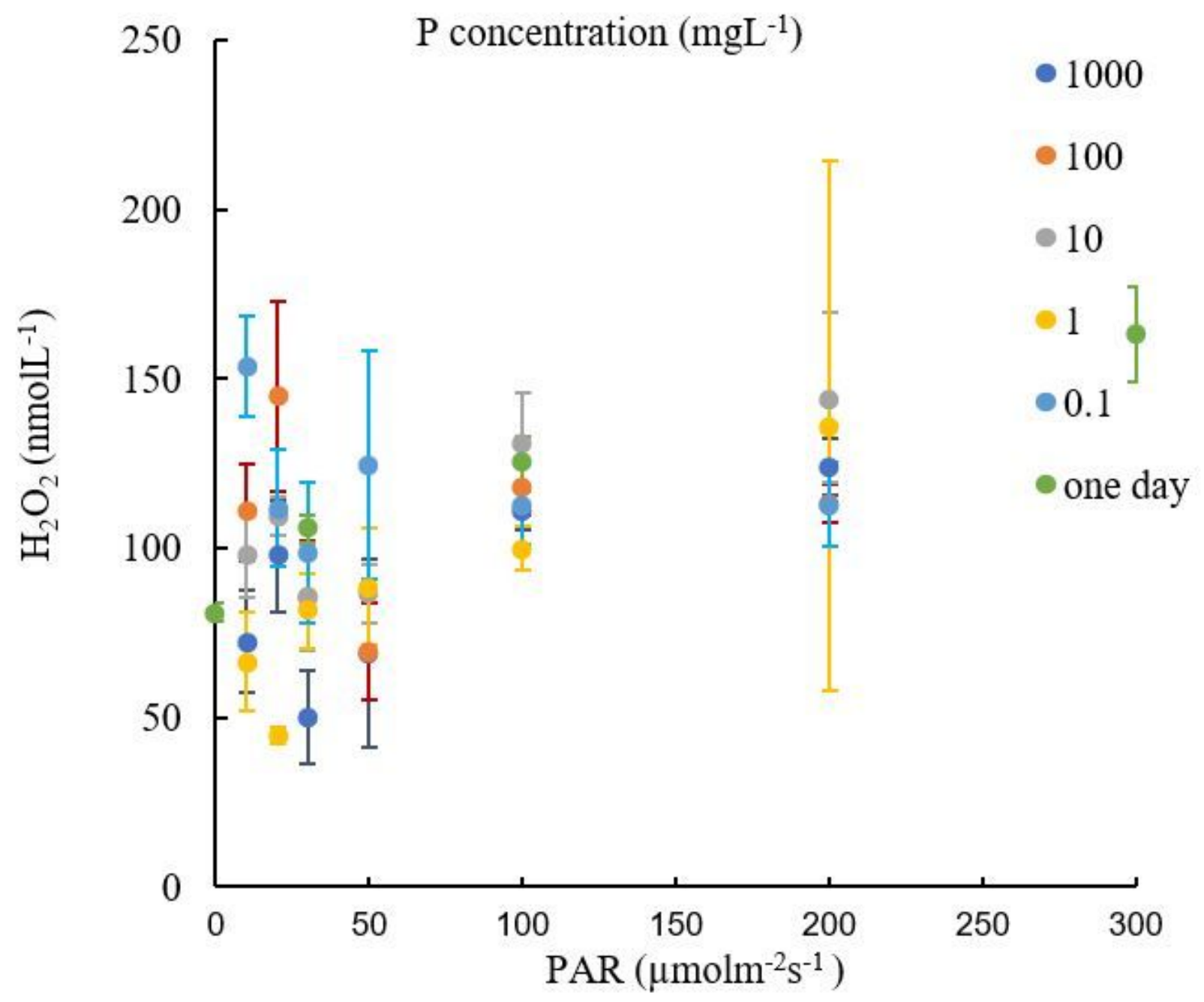

Figure 2

H2O2 concentration for different PAR intensity levels and for each phosphorus concentration level (mgL1). Vertical bars indicate standard deviation. 


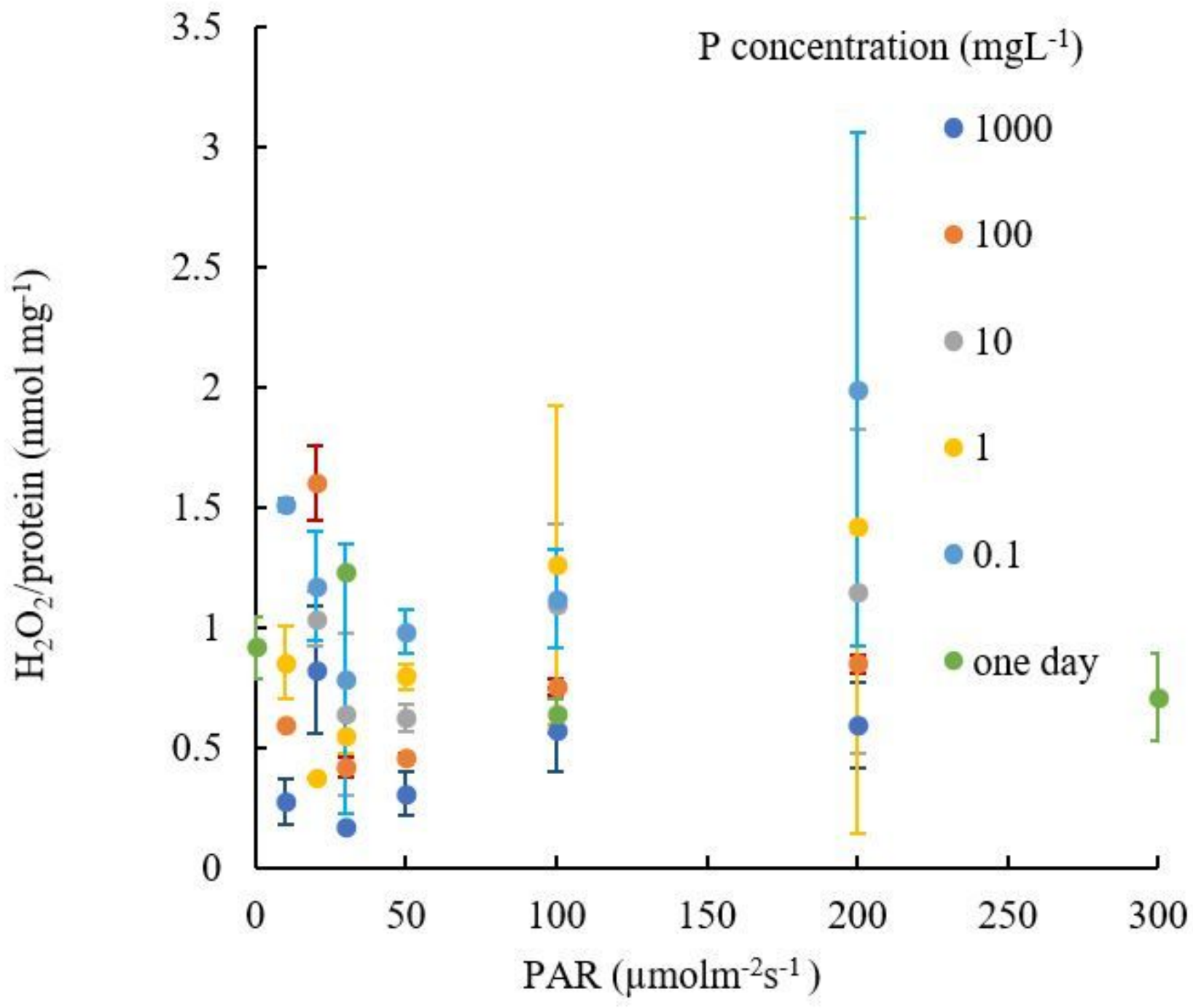

Figure 3

H2O2 content per protein for different PAR intensity levels and for each phosphorus concentration level (mgL-1). Vertical bars indicate standard deviation. 


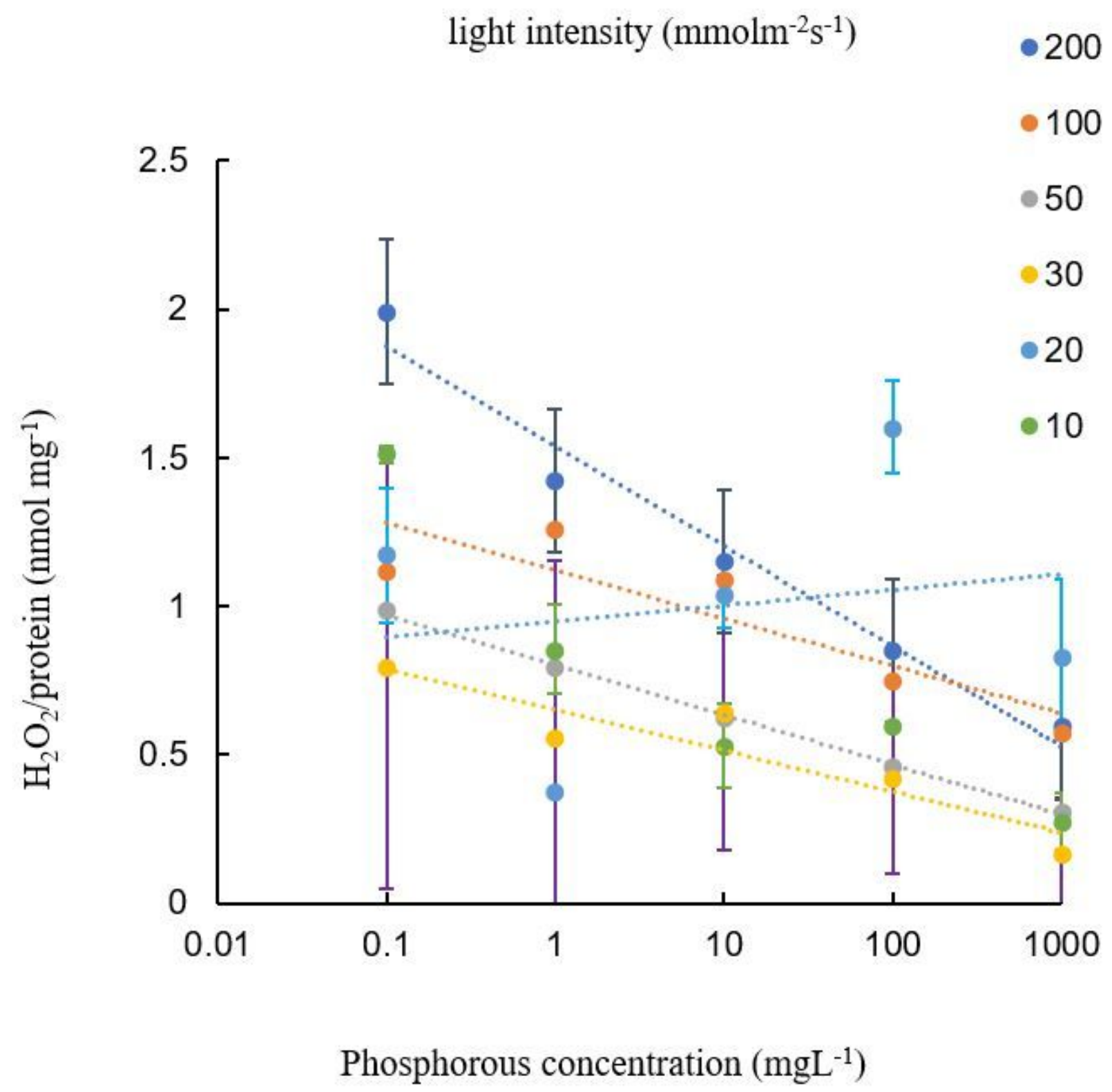

Figure 4

H2O2 content per protein for different phosphorus concentration level (mgL-1) and for each PAR intensity level $(\mu \mathrm{molm}-2 \mathrm{~s}-1)$. Vertical bars indicate standard deviation. Dotted lines show the approximate relation for each light intensity. 


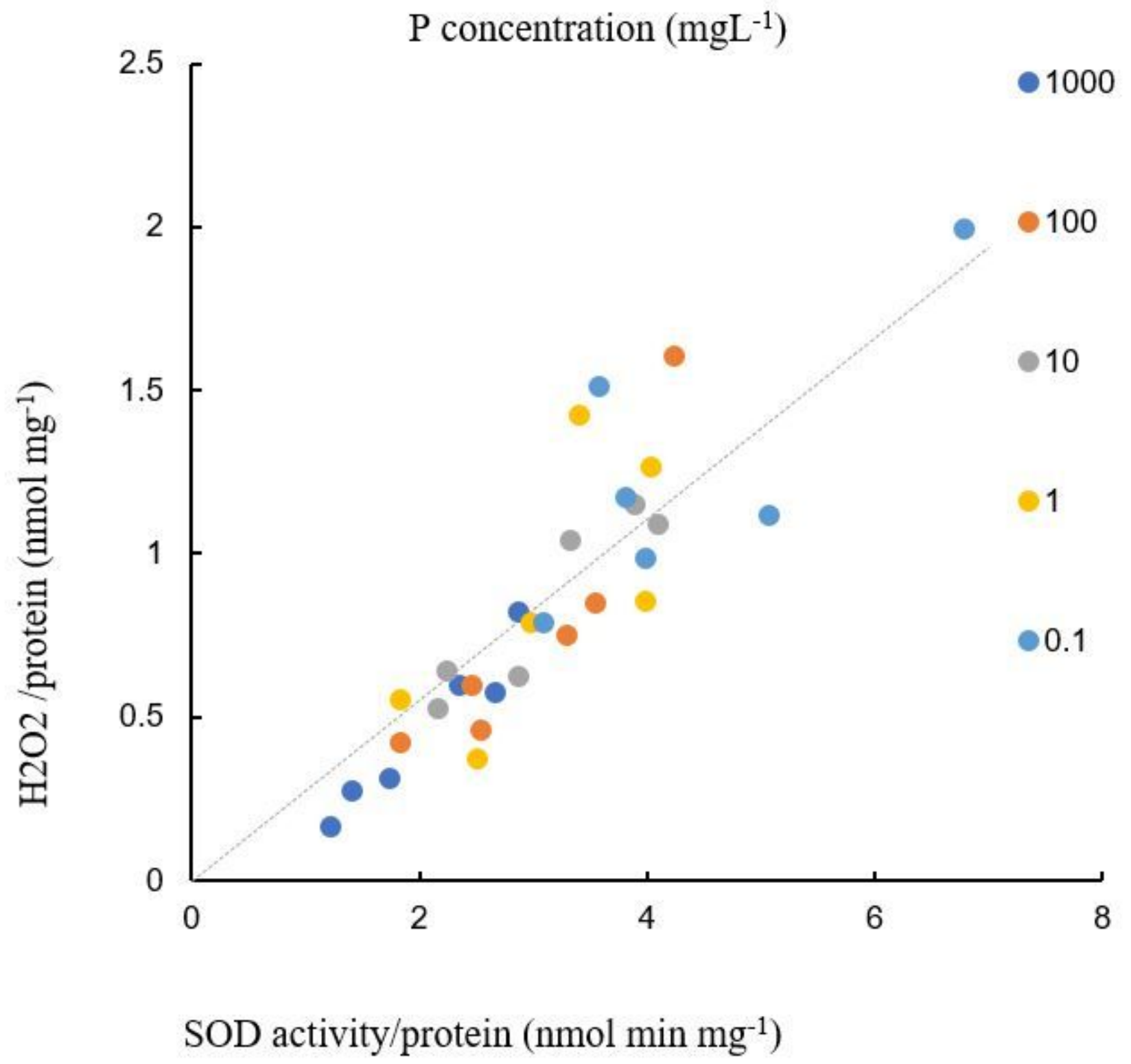

Figure 5

SOD activity per protein for different phosphorus concentration level (mgL-1) and for each PAR intensity level $(\mu \mathrm{molm}-2 \mathrm{~s}-1)$. The approximate relation is shown by the diagonal line. 


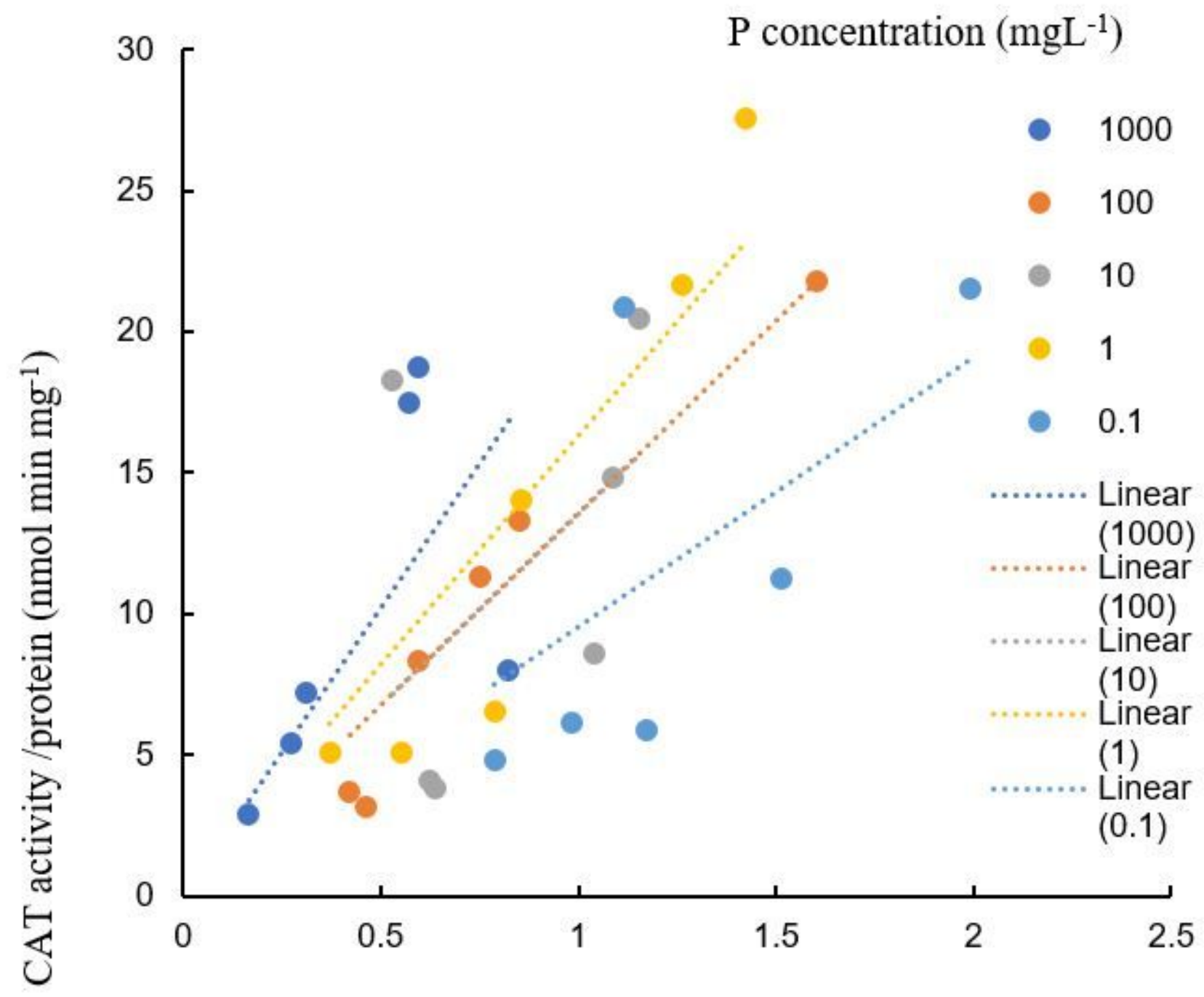

\section{$\mathrm{H} 2 \mathrm{O} 2 /$ protein $\left(\mathrm{nmol} \mathrm{mg}^{-1}\right)$}

Figure 6

CAT activity per protein for different phosphorus concentration levels (mgL-1) and for each PAR intensity level ( $\mu \mathrm{molm}-2 \mathrm{~s}-1)$. Dotted lines indicate the approximate lines for each phosphorus concentration. 


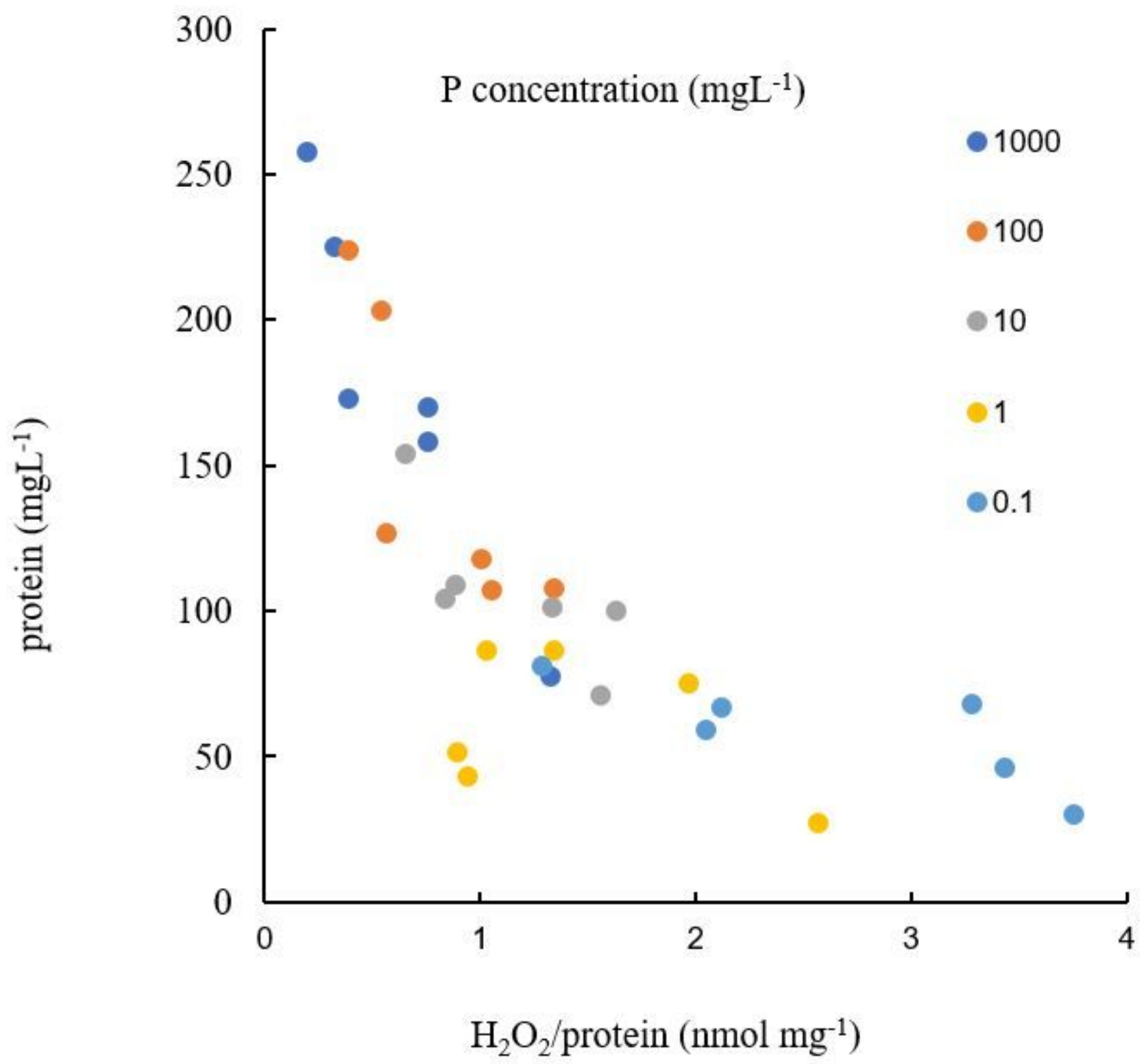

Figure 7

Protein content in water for different phosphorus concentration levels $(\mathrm{mg} / \mathrm{L})$ and for each PAR intensity level $(\mu \mathrm{molm}-2 \mathrm{~s}-1)$ 


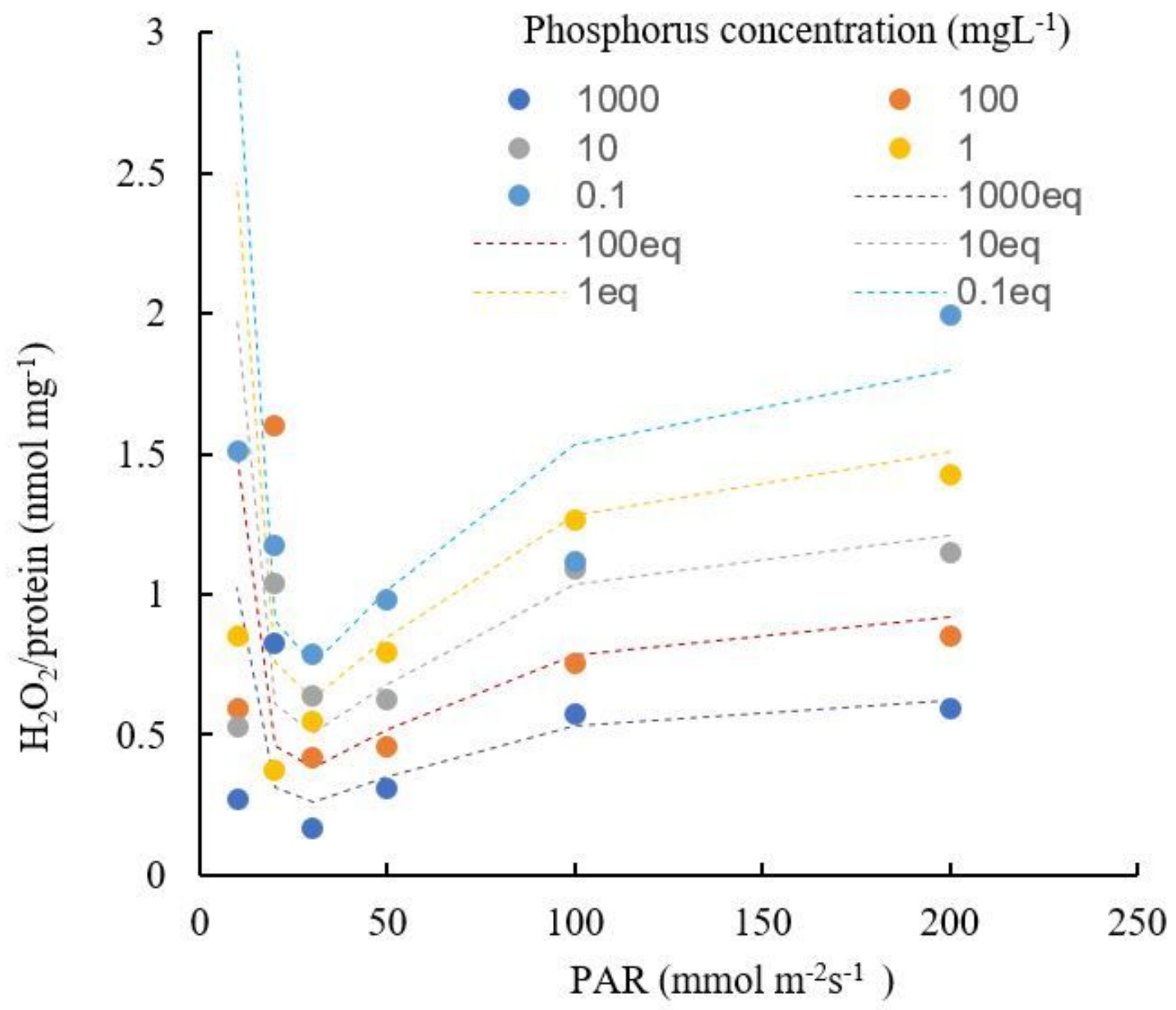

Figure 8

The simulated results of $\mathrm{H} 2 \mathrm{O} 2$ /protein by equation (1) compared with experimental results. 


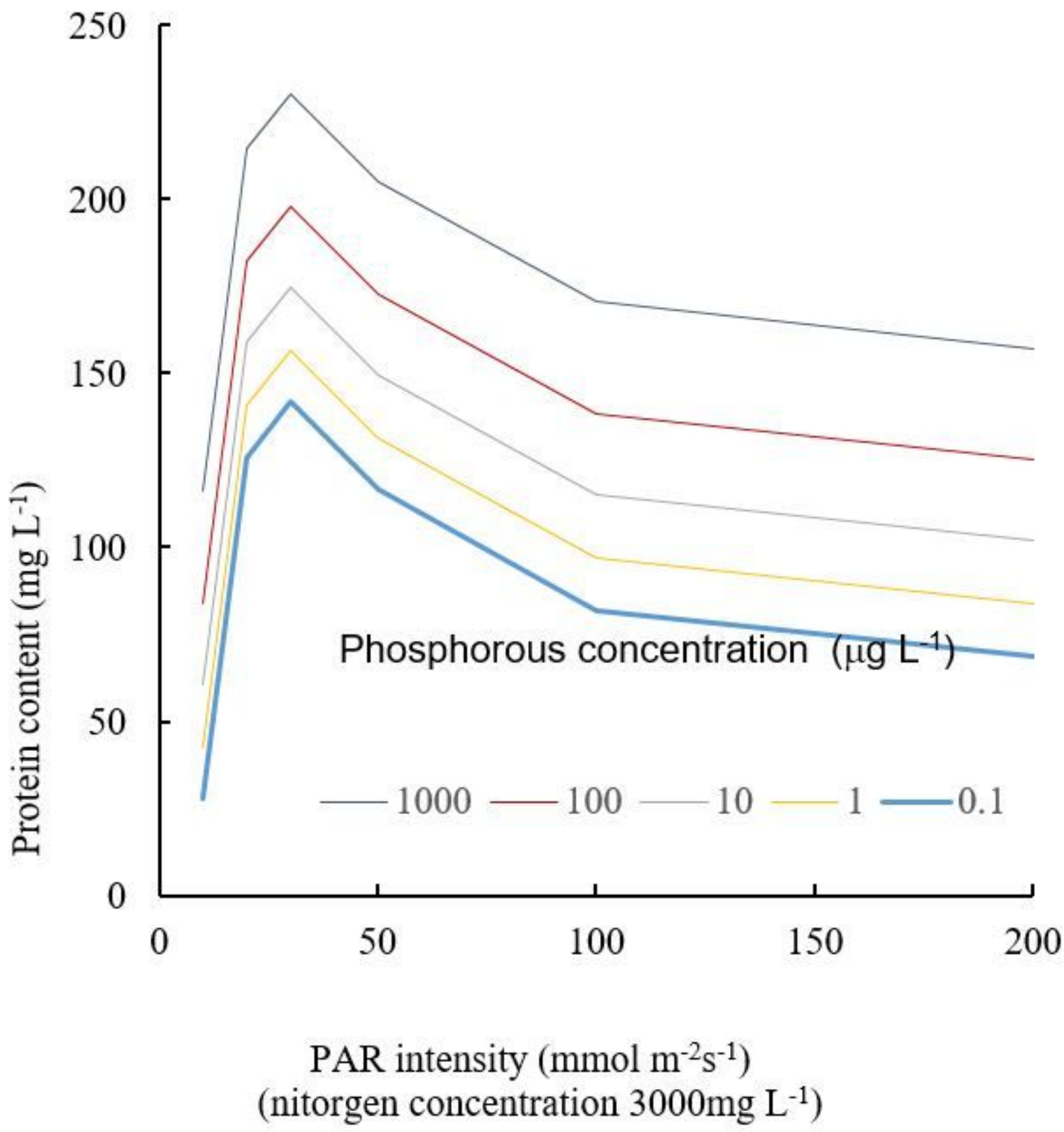

Figure 9

The simulated results of protein content by equation (2) 